\title{
The Effect of the Ultra-High-Pressure Homogenization of Protein Encapsulants on the Survivability of Probiotic Cultures after Spray Drying
}

\author{
Kevin E. Mis-Solval ${ }^{1, *(\mathbb{C}, \text { Nan Jiang }}{ }^{1}$, Meilan Yuan ${ }^{2}$, Kay H. Joo ${ }^{3}$ and George A. Cavender ${ }^{3, * \mathbb{C}}$ \\ 1 Department of Food Science and Technology, University of Georgia, Griffin, GA 30223, USA; \\ nanjiang6@uga.edu \\ 2 School of Life Sciences, Jiangxi Science and Technology Normal University, Nanchang 330013, China; \\ yuanmimi@163.com \\ 3 Department of Food Science and Technology, University of Georgia, Athens, GA 30602, USA; \\ khjoo16@uga.edu \\ * Correspondence: kmissolval@uga.edu (K.E.M.-S.); cavender@uga.edu (G.A.C.); \\ Tel.: +1-(770)-412-4741 (K.E.M.-S.); +1-(706)-542-1092 (G.A.C.)
}

Received: 15 November 2019; Accepted: 13 December 2019; Published: 17 December 2019

\begin{abstract}
Interest in probiotic foods and ingredients is increasing as consumers become more aware of their potential health benefits. The production of these products often involves the use of dry culture powders, and the techniques used to produce such powders often suffer from significant losses of viable cells during drying or require the use of expensive drying technologies with limited throughput (e.g., freeze drying). In this study, the authors examined whether culture survivability during spray drying could be increased via the treatment of two common protein encapsulants with ultra-high-pressure homogenization (UHPH). Lactobacillus plantarum NRRL B-1927 (also known as ATCC 10241), a probiotic strain, was suspended in either soy protein isolate (SPI) or whey protein isolate (WPI) which had been either treated with UHPH at $150 \mathrm{Mpa}$ or left untreated as a control. The suspensions were then dried using either concurrent-flow spray drying (CCSD), mixed-flow spray drying (MFSD) or freeze drying (FD) and evaluated for cell survivability, particle size, moisture content and water activity. In all cases, UHPH resulted in equal or greater survivability among spray dried cultures, showed reductions in particle size measures and, except for one marginal case (CCFD SPI), significantly reduced the moisture content of the dried powders. The combination of these findings strongly suggests that UHPH could allow probiotic powder manufacturers to replace freeze drying with spray drying while maintaining or increasing product quality.
\end{abstract}

Keywords: probiotic encapsulation; high-pressure homogenization; spray drying

\section{Introduction}

As consumers become more aware of the contribution of gut microbiota to human health, the market for probiotic foods and supplements is growing significantly [1]. While people can, and often do, add probiotic cultures to their diet using naturally fermented foods, many rely on formulated products (including supplements) due to issues of taste/preference or a desire for a specific probiotic culture [2,3]. To supply the cultures needed for these products, commercial operations must be able to grow sufficient numbers of bacteria, separate them from the growth medium, and preserve them in some fashion for future use [3]. While freeze drying is used for such preservation, owing to its exceptional ability to preserve cell viability, several factors make it less than ideal, including the length of time needed for drying, the discontinuous nature of the process and the high cost of the process. Though these shortcomings are not as critical when producing cultures for the inoculation of foods for 
fermentation, if the goal is to fortify a food with high levels of viable probiotic bacteria, or create a nutritional supplement, they can be significant [4]. Another method of preserving probiotic cultures that has been investigated is spray drying. This technology exposes a fine mist of liquid to high velocity hot, dry air in order to quickly drive off water, creating a fine powder that can be readily separated from the airstream via centrifugal separation or other techniques [5]. While rapid, continuous, and inexpensive, the process can greatly reduce probiotic culture counts due to the high temperatures involved $[4,6]$. One way to limit this problem is to encapsulate the cultures using various biopolymers, which create a protective matrix surrounding cells, greatly increasing survivability. However, even with this technique, significant viable cell losses can be seen [7]. Though many different substances, including polysaccharides, fats, waxes, and various other food ingredients can be used to encapsulate probiotic cultures, dairy derived ingredients are fairly common, providing protection not only during drying, but also during digestion of the encapsulated powders $[7,8]$. Conventionally, liquid foods can be spray dried under concurrent (CC) and mixed-flow (MX) conditions. According to Cal and Sollohub [9], most heat-sensitive products are spray dried under CC, while MX spray drying allows the production of agglomerated particles in a relative small chamber. Although several authors have reported the microencapsulation of probiotics using CC spray drying [10,11], the effect of MX spray drying on the quality of probiotic powders has not been investigated in detail.

While dairy products/ingredients provide benefits in encapsulating probiotic cultures, they can pose concerns for product manufacturers. These issues include the potential introduction of milk allergens to non-dairy products, the creation of products unsuitable for those who do not consume dairy products for religious or ethical reasons (e.g., vegans) and, depending on the dairy ingredient used, issues with lactose intolerance. Soy-based ingredients have seen some limited investigation as potential replacements, with Hadzieva, Mladenovska, Crcarevska, Dodov, Dimchevska, Geškovski, Grozdanov, Popovski, Petruševski, Chachorovska, Ivanovska, Petruševska-Tozi, Ugarkovic and Goracinova [6] combining soy protein isolate (SPI) with alginate and discovering that some combinations having excellent survivability, while other saw rates below $30 \%$, while Chávez and Ledeboer [12] found that SPI's ability to protect cultures during drying varied depending on the drying technique and presence of other compounds, with SPI alone resulting in as low as $28 \%$ survival.

Structural differences in proteins likely explain the performance gap between dairy products and soy products during encapsulation, as protein-protein interactions and protein-cell wall interactions are responsible for the immobilization of bacterial cells [13].

While there may be multiple ways to solve the shortcomings of soy-based encapsulants, the simplest might be to modify their structural components in a manner that would encourage the formation of intermolecular bonds, allowing them to better encapsulate bacterial cells. One technique that has been shown to accomplish this type of modification in other protein-rich ingredients is ultra-high-pressure homogenization (UHPH). This process pumps fluids at pressures in excess of $100 \mathrm{MPa}$, forcing them through a valve or other pressure release component, exposing them to extreme shear that can reduce particle size [14,15], alter proteins [16], increase viscosity [17] and encourage the formation of intermolecular complexes [18].

This study aimed to examine the effect that subjecting two protein-based encapsulants (SPI and whey protein isolate (WPI)) to UHPH would have on the survivability of probiotic cultures during drying techniques commonly used to produce probiotic powders and to determine whether the magnitude of the effect on that process would differ between the two. Additionally, the authors aimed to characterize any potential difference in the particle size or the moisture content of the dried powders, which should provide some initial insight into future storage issues. It was hypothesized that UHPH treatment would increase the ability of the encapsulants to form various bonds, thereby increasing their protective effect. 


\section{Materials and Methods}

\subsection{Materials}

Dehydrated peptone, de Man, Rogosa \& Sharpe (MRS) broth and MRS agar (Thermo Fisher Scientific, Waltham, Massachusetts, USA) were prepared according to label instructions prior to sterilization. Powdered SPI (ProFam 646, Archer Daniels Midland Company, Chicago, IL, USA) and Powdered WPI (ISOPURE, The Isopure company, Downers Grove, IL, USA) were dissolved in reverse osmosis water to yield $9 \%$ suspensions that were stored at $4{ }^{\circ} \mathrm{C}$ for $24 \mathrm{~h}$ prior to any UHPH or culture suspension in order to ensure full hydration of the powders and provide a sufficiently low inlet temperature during processing. A pure culture sample of Lactobacillus plantarum, (NRRL B-1927 aka ATCC 10241) originally isolated from sauerkraut and frequently identified as a probiotic [19-21], was obtained from the USDA-ARS Culture collection (Peoria, IL, USA) and used to propagate all cultures used in this study.

\subsection{Preparation of Probiotic Cultures}

Probiotic cultures were propagated by following the conditions recommended by the USDA-ARS Culture collection [22]. First, a loop of culture was transferred into a $9 \mathrm{~mL}$ culture tube containing MRS broth. Tubes were capped and incubated at $37^{\circ} \mathrm{C}$ for $48 \mathrm{~h}$, before being used to inoculate flasks containing $3 \mathrm{~L}$ of MRS broth, which were then incubated for an additional $48 \mathrm{~h}$. Cultures were then stored at $4{ }^{\circ} \mathrm{C}$ for up to $24 \mathrm{~h}$ prior to centrifugation. After agitation, cultures from a given flask were transferred into $500 \mathrm{~mL}$ centrifuge bottles and a refrigerated ultracentrifuge (Sorvall RC-6 plus, Thermo Fisher Scientific, Waltham, MA, USA) fitted with an appropriate rotor (Fiberlite F10-6x500, Thermo Fisher Scientific, Waltham, MA, USA) and kept at $4{ }^{\circ} \mathrm{C}$ was used to centrifuge the cultures at $5000 \times g$ for $15 \mathrm{~min}$. After decanting the supernatant from each bottle, each pellet was re-suspended using $50 \mathrm{~mL}$ of $0.1 \%$ peptone water. Suspended pellets were then combined and centrifuged again for $10 \mathrm{~min}$ to yield a single pellet for encapsulant fortification.

\subsection{Preparation of Probiotic Suspensions}

Two suspensions were prepared by mixing $90 \mathrm{~g}$ of either SPI or WPI in $1 \mathrm{~L}$ of distilled water. Then, the suspensions were UHPH processed at $150 \mathrm{MPa}$ using a dual-intensifier continuous high-pressure homogenizing system (Stansted nm-gen 7900, Stansted Fluid Power, Stansted, England) that had been fitted with a stainless steel metering valve (Model 60vrmm4882, Autoclave Engineers, Fluid Components, Erie, PA, USA) at the outlet and modified to feed from a 6 L vessel that was pressurized with compressed air at approximately $550 \mathrm{kPa}$. The flow rate was adjusted via the metering valve to $1 \pm 0.25 \mathrm{~L} / \mathrm{min}$, and the collected samples were refrigerated immediately after collection and allowed to cool to at least $20^{\circ} \mathrm{C}$ before any cultures were added. These particular UHPH processing parameters were chosen based on structural/functional effects seen in previous works $[17,18,23-25]$ as well as the fact that they fall within the working range of many commonly available UHPH equipment. Encapsulants for control trials were used directly from refrigerated storage. Probiotic pellets were dispersed in control- and UHPH-treated suspensions to produce probiotic suspensions $\left(\sim 10^{9} \mathrm{CFU} / \mathrm{mL}\right)$ which were stored under refrigeration for up to $48 \mathrm{~h}$ prior to drying to ensure complete chilling and to facilitate transit between processing locations.

\subsection{Drying of Samples}

Aliquots (1L) of each probiotic suspension were spray dried (SD) under concurrent (CC) and/or mixed-flow (MX) conditions using a pilot-scale spray drier (Anhydro, PSD 52, Copenhagen, Denmark) at the pilot plant of the University of Georgia (UGA) Food Product Innovation and Commercialization Center (Food PIC-Griffin, GA, USA). In CC spray drying, both drying air and atomized droplets of liquid feed are introduced from the top and exit at the bottom of the drying chamber (DC) of the spray dryer; however, in MX spray drying, drying air enters the DC from the top and the liquid feed is atomized from the bottom. Both exit at the bottom of the DC (Figure 1). Most heat-sensitive 
products are dried under CC configurations, while heat-stable products are processed in MX drying designs [9]. In both $\mathrm{CC}$ and $\mathrm{MX}$, the inlet temperature was set at $140{ }^{\circ} \mathrm{C}$ and outlet was kept at $80 \pm 2{ }^{\circ} \mathrm{C}$. The feed flow rate was set between 1.5 and $1.75 \mathrm{~L} / \mathrm{h}$. Drying conditions were selected based on work previously performed on Lactobacillus plantarum strains using various encapsulants [10,26,27]. Concurrently, the probiotic suspensions were also freeze dried (FD). Freeze drying was carried out by freezing $1 \mathrm{~L}$ of probiotic suspensions for $12 \mathrm{~h}$. Frozen samples were loaded into pilot-scale lyophilizer (Virtis, the Virtis Company, Gardiner, NY, USA) and dried at $-55^{\circ} \mathrm{C}$ for $72 \mathrm{~h}$ to produce freeze-dried powders. Freeze-dried samples were milled using a high-performance blender (Vitaminix 7500, Olmsted Township, Olmsted Township, OH, USA). Dried powders were stored at $-20{ }^{\circ} \mathrm{C}$ in a desiccator until the day of analyses (no more than $48 \mathrm{~h}$ for enumeration and no more than 5 days for physical properties), and all trials were performed in triplicate.
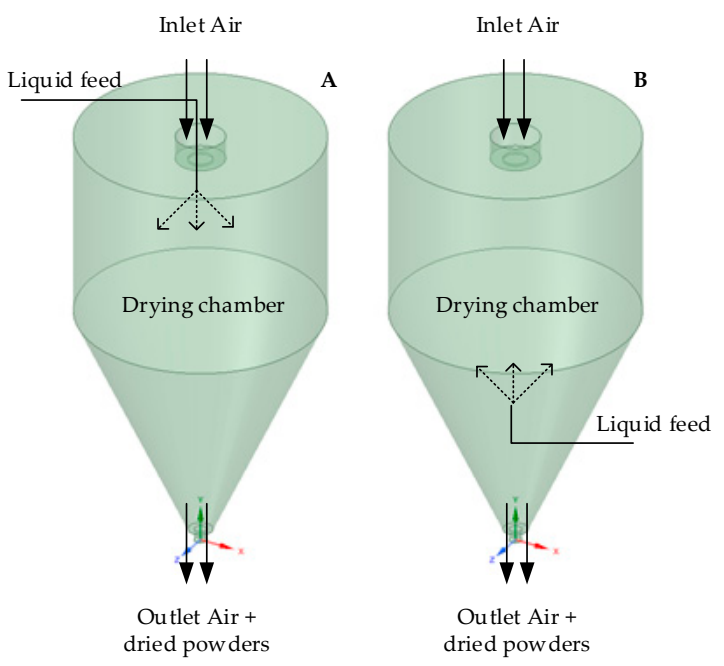

Figure 1. Spray drying configurations: (A) concurrent (CC) and (B) mixed-flow (MX).

\subsection{Enumeration of Probiotic Cultures}

Cell counts of L. plantarum (NRRL B-1927) were quantified in probiotic suspensions and dried powders by following a modified method described by Reyes, Chotiko, Chouljenko, Campbell, Liu, Theegala and Sathivel [10]. Briefly, $0.1 \mathrm{~mL}$ of probiotic suspensions or $1 \mathrm{~g}$ of dried powders were serially diluted in sterile Butterfield's phosphate buffer and $0.1 \mathrm{~mL}$ of each dilution was pour plated using $100 \mathrm{~mm}$ diameter plates and MRS agar. Dried powders were allowed to fully hydrate in the buffer solution prior to dilution to ensure homogeneous samples. All plating was performed in triplicate, and plates were incubated for $48 \mathrm{~h}$ at $37^{\circ} \mathrm{C}$ under aerobic conditions before cell colonies were counted. For ease of comparison, results were expressed as the Log of colony forming units (CFU) per gram of dried solids (Log CFU/g).

\subsection{Physical Properties of Dried Powders}

\subsubsection{Moisture Content and Water Activity $\left(a_{w}\right)$}

The moisture content of the powders was determined by moisture analyzer (HR73 Halogen Moisture Analyzer, Mettler-Toledo $\mathrm{GmbH}$, Greifensee, Switzerland). Water activity $\left(\mathrm{a}_{\mathrm{w}}\right)$ values were obtained by using a water activity meter (AquaLabSeries 4 TE, Decagon Devices, Inc., Pullman, WA, USA).

\subsubsection{Particle Size Distribution}

The particle size distribution of powdered samples was tested using an automated particle size analyzer equipped with laser diffraction (Model PSA 1190, Anton Paar GmbH, Graz, Austria). Briefly, dried powders were placed into the unit's feed hopper and transported via Venturi/free fall to the analytical area where they were automatically illuminated with three lasers from low to high angles 
and the diffracted light was analyzed by the system. The whole light scatter pattern was collected and used to calculate the particle size distribution using the Modified Michelson Interferometer (MIE) method which quantifies the angular distribution of backscattered light. The results were reported for D10, D50, and D90 which are the volume diameters of the particles at $10 \%, 50 \%$, and $90 \%$ cumulative volume respectively and the span value (spread of particles) was calculated by following the method described by Mis Solval, et al. [28].

\subsection{Statistical Analysis}

The statistical significance of the observed differences among the means of experimental results was determined by Analysis of Variance (ANOVA) using RStudio statistical software version 1.1.463 (RStudio, Inc. Boston, MA, USA) and followed by post-hoc Tukey's studentized range tests at an alpha of 0.05. Pearson's bivariate correlation was used to evaluate the correlations between cell survival in spray and/or freeze-dried powders and particle size distribution values.

\section{Results}

\subsection{Probiotic Survivablity}

Probiotic counts before and after drying are presented in Table 1. In all cases, the UHPH-treated encapsulants were either better or equally good at protecting the probiotic cultures during drying than the NO-UHPH-treated encapsulants, and among the spray dried samples, survivability exceeded the rates seen during freeze drying with untreated encapsulants.

Table 1. Cell counts (Log (CFU/g solids)) of L. plantarum (NRRL B-1927) encapsulated in ultra-high- pressure homogenized soy protein isolate (SPI) and/or whey protein isolate (WPI) suspensions after spray drying.

\begin{tabular}{|c|c|c|c|c|c|c|c|}
\hline \multirow{3}{*}{$\begin{array}{l}\text { Drying } \\
\text { Method }\end{array}$} & \multirow{3}{*}{ Encap. Mat. } & \multicolumn{3}{|c|}{ NO-UHPH } & \multicolumn{3}{|c|}{ UHPH (150 Mpa) } \\
\hline & & \multicolumn{2}{|c|}{ Log CFU/g Solids } & \multirow{2}{*}{ Cell Survival (\%) } & \multicolumn{2}{|c|}{ Log CFU/g Solids } & \multirow{2}{*}{ Cell Survival (\%) } \\
\hline & & $\begin{array}{l}\text { Before } \\
\text { Drying }\end{array}$ & $\begin{array}{c}\text { After } \\
\text { Drying }\end{array}$ & & $\begin{array}{l}\text { Before } \\
\text { Drying }\end{array}$ & $\begin{array}{c}\text { After } \\
\text { Drying }\end{array}$ & \\
\hline $\mathrm{CC}$ & SPI & $8.67 \pm 0.32$ & $8.43 \pm 0.08$ & $6.56 \pm 1.75^{\mathrm{d}, \mathrm{B}}$ & $9.27 \pm 010$ & $8.47 \pm 0.17$ & $20.10 \pm 0.56^{\mathrm{d}, \mathrm{A}}$ \\
\hline $\mathrm{CC}$ & WPI & $9.22 \pm 0.02$ & $8.46 \pm 0.01$ & $17.37 \pm 0.37^{\mathrm{c}, \mathrm{B}}$ & $9.20 \pm 0.08$ & $8.93 \pm 0.04$ & $53.39 \pm 5.58^{\mathrm{a}, \mathrm{b}, \mathrm{A}}$ \\
\hline FD & SPI & $9.16 \pm 0.30$ & $7.87 \pm 0.07$ & $5.13 \pm 0.81^{d, B}$ & $9.27 \pm 010$ & $8.78 \pm 0.11$ & $32.77 \pm 7.65^{b, c, d, A}$ \\
\hline FD & WPI & $9.02 \pm 0.02$ & $8.66 \pm 0.08$ & $43.87 \pm 7.98^{\mathrm{b}, \mathrm{A}}$ & $9.20 \pm 0.08$ & $9.02 \pm 0.10$ & $67.29 \pm 14.97^{\mathrm{a}, \mathrm{A}}$ \\
\hline
\end{tabular}

Means \pm Standard Deviation (SD). $n=3$. Survival rates followed by different miniscule (a, b, c, etc.) letters in the same column are significantly different $(p<0.05)$. Survival rates followed by different majuscule $(A, B, C$, etc.) letters in the same row are significantly different $(p<0.05)$. $C C=$ concurrent spray drying, $\mathrm{MX}=$ mixed-flow spray drying; $\mathrm{FD}=$ freeze drying; $\mathrm{SPI}=$ soy protein isolate; $\mathrm{WPI}=$ whey protein isolate.

In the case of the NO-UHPH-treated samples, higher cell survival was obtained in MX powders compared to CC and freeze dried (FD) powders and with WPI than with SPI powders. For the UHPH-treated encapsulants, significantly $(p<0.05)$ higher cell survival was also observed in the WPI than in the SPI samples. However, same cell survival was observed in WPI dried in CC, MX and/or FD. Interestingly, major improvements in cell survival were observed in the UHPH-treated encapsulants dried in CC SD and FD.

\subsection{Particle Size Distribution}

Particle size distribution data are presented in Table 2. It was seen that NO-UHPH-treated WPI Spray Dried samples had smaller particle sizes compared to NO-UHPH-treated SPI SD powders. However, the same effect was not seen in UHPH-treated samples. Of note, UHPH was found to decrease particle size distribution $\left(\mathrm{D}_{10}, \mathrm{D}_{50}\right.$, and $\left.\mathrm{D}_{90}\right)$ for every drying condition and encapsulant, except for freeze-dried SPI. UHPH also slightly increased the spread of the particle size distribution for all drying conditions and encapsulants, except for WPI in MXSD. Furthermore, in the spray dried samples, UHPH caused drastic reduction in both D10 and D90 measures. 
Table 2. Particle size distribution values of dried probiotic powders containing L. plantarum (NRRL B-1927).

\begin{tabular}{|c|c|c|c|c|c|c|c|c|c|}
\hline \multirow{3}{*}{$\begin{array}{l}\text { Drying } \\
\text { Method }\end{array}$} & \multirow{3}{*}{ Encap. Mat. } & \multicolumn{4}{|c|}{ NO-UHPH } & \multicolumn{4}{|c|}{ UHPH (150 Mpa) } \\
\hline & & \multicolumn{4}{|c|}{ Particle Size Distribution } & \multicolumn{4}{|c|}{ Particle Size Distribution } \\
\hline & & $D_{10}(\mu \mathrm{m})$ & $\mathrm{D}_{50}(\mu \mathrm{m})$ & $\mathrm{D}_{90}(\mu \mathrm{m})$ & Span & $D_{10}(\mu \mathrm{m})$ & $D_{50}(\mu \mathrm{m})$ & $\mathrm{D}_{90}(\mu \mathrm{m})$ & Span \\
\hline $\mathrm{CC}$ & SPI & $4.71 \pm 0.29^{\mathrm{c}, \mathrm{A}}$ & $27.54 \pm 0.26^{\mathrm{c}, \mathrm{A}}$ & $55.52 \pm 0.13^{\mathrm{c}, \mathrm{A}}$ & $1.85 \pm 0.02 \mathrm{~d}, \mathrm{~B}$ & $1.74 \pm 0.02^{c, B}$ & $15.30 \pm 0.10^{\mathrm{c}, \mathrm{B}}$ & $33.09 \pm 0.09 \mathrm{c}, \mathrm{B}$ & $2.05 \pm 0.01^{c, A}$ \\
\hline $\mathrm{CC}$ & WPI & $3.96 \pm 0.10^{c, d, A}$ & $26.32 \pm 0.17^{\mathrm{c}, \mathrm{A}}$ & $55.46 \pm 0.23^{c, A}$ & $1.96 \pm 0.01 \mathrm{~d}, \mathrm{~B}$ & $1.79 \pm 0.01 \mathrm{c}, \mathrm{B}$ & $14.69 \pm 0.15^{\mathrm{c}, \mathrm{B}}$ & $32.28 \pm 0.25^{\mathrm{c}, \mathrm{B}}$ & $2.08 \pm 0.02^{c, A}$ \\
\hline MX & SPI & $3.28 \pm 0.08^{\mathrm{c}, \mathrm{d}, \mathrm{A}}$ & $28.15 \pm 0.05^{\mathrm{c}, \mathrm{A}}$ & $67.81 \pm 0.17^{\mathrm{c}, \mathrm{A}}$ & $2.29 \pm 0.01^{c, B}$ & $1.36 \pm 0.03 \mathrm{~d}, \mathrm{~B}$ & $8.92 \pm 0.02 \mathrm{~d}, \mathrm{~B}$ & $26.07 \pm 0.22 \mathrm{~d}, \mathrm{~B}$ & $2.77 \pm 0.02^{\mathrm{b}, \mathrm{A}}$ \\
\hline MX & WPI & $1.59 \pm 0.04 \mathrm{~d}, \mathrm{~A}$ & $12.94 \pm 0.41 \mathrm{~d}, \mathrm{~A}$ & $37.39 \pm 0.50 \mathrm{~d}, \mathrm{~A}$ & $2.77 \pm 0.05 \mathrm{~b}, \mathrm{~A}$ & $1.44 \pm 0.03 \mathrm{~d}, \mathrm{~B}$ & $10.47 \pm 0.17 \mathrm{~d}, \mathrm{~B}$ & $30.66 \pm 0.97 \mathrm{c}, \mathrm{d}, \mathrm{B}$ & $2.79 \pm 0.05^{\mathrm{b}, \mathrm{A}}$ \\
\hline FD & SPI & $19.09 \pm 0.93 \mathrm{a}, \mathrm{A}$ & $92.62 \pm 4.07$ a,A & $278.85 \pm 12.46^{\mathrm{a}, \mathrm{A}}$ & $2.73 \pm 0.04^{b, B}$ & $16.50 \pm 0.06^{\mathrm{a}, \mathrm{B}}$ & $96.02 \pm 1.37 \mathrm{a}, \mathrm{A}$ & $287.91 \pm 3.98$ a,A & $2.83 \pm 0.02 \mathrm{~b}, \mathrm{~A}$ \\
\hline FD & WPI & $15.49 \pm 2.11^{\mathrm{b}, \mathrm{A}}$ & $75.66 \pm 1.75^{\mathrm{b}, \mathrm{A}}$ & $248.69 \pm 3.70^{\mathrm{b}, \mathrm{A}}$ & $3.09 \pm 0.15^{\mathrm{a}, \mathrm{B}}$ & $10.20 \pm 0.07 \mathrm{~b}, \mathrm{~B}$ & $60.50 \pm 0.03 \mathrm{~b}, \mathrm{~B}$ & $219.43 \pm 2.49^{\mathrm{b}, \mathrm{B}}$ & $3.46 \pm 0.04 \mathrm{a}, \mathrm{A}$ \\
\hline
\end{tabular}

Means $\pm \mathrm{SD}, n=3$. Particle sizes followed by different miniscule (a, b, c, etc.) letters in the same column are significantly different $(p<0.05)$. Particle sizes followed by different majuscule

(A, B, C, etc.) letters in the same row for a given measure $\left(\mathrm{D}_{10}, \mathrm{D}_{50}\right.$, span, etc.) are significantly different $(p<0.05)$. CC $=$ concurrent spray drying, $M X=$ mixed-flow spray drying; $F D=$ freeze drying; SPI = soy protein isolate; WPI = whey protein isolate; Dx = xth percentile particle size. 
Effect of Particle Size and Survival of Probiotic Cells

Due to the differences in the production of spray dried and freeze-dried probiotic powders, the correlation analysis between the particle size distribution values of SD powders and cell survival was conducted independently from that of FD powders.

a. Spray Dried Powders

The analysis of correlation, shown in Figure 2, indicated that there was a highly significant $(p<$ 0.05) negative correlation between cell survival and particle size distribution values $\left(D_{10}, D_{50}, D_{90}\right.$, and span) which suggests that the smaller the particle size of the spray dried powders, the higher the survival of the probiotic cells (up to certain point). Moreover, there was a significant $(p<0.05)$ positive correlation (0.65) between the span value and the cell survival of probiotic cells. Higher span values are observed in agglomerated particles (powders produced under MX conditions). Hence the results suggest that the higher the span value, the higher the cell survival.

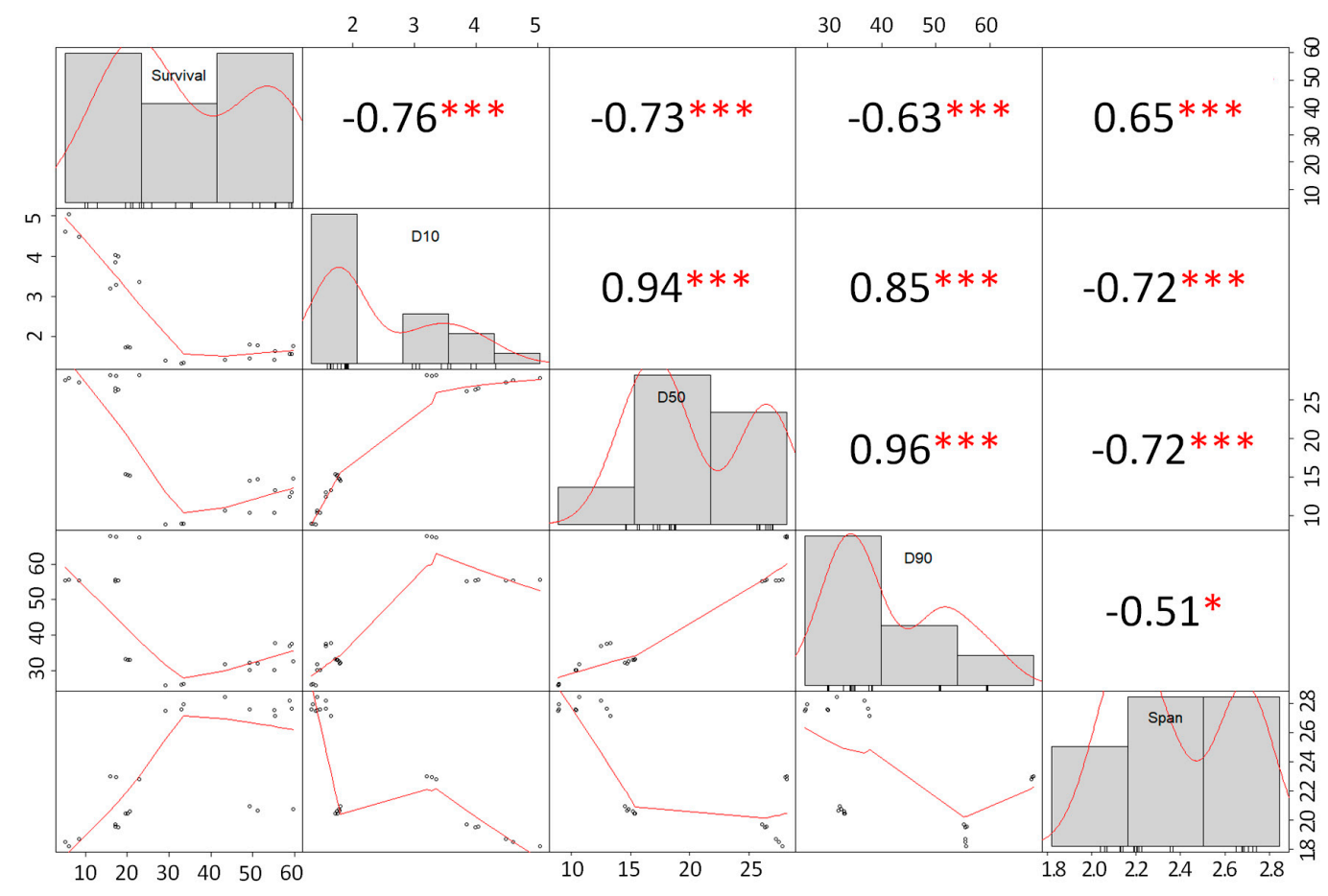

Figure 2. Analysis of correlation between particle size distribution (D10, D50, D90, and span) vs. the survival of probiotic cells in spray dried powders (units, survival $=\%, \mathrm{D} 10, \mathrm{D} 50, \mathrm{D} 90=\mu \mathrm{m}$ ). The distribution of each variable is presented in the diagonal. On the left of the diagonal, the bivariate scatter plots with a fitted line are shown. The output numbers represent the correlation coefficient. The stars represent the $p$-value of the correlations: ${ }^{*} p<0.05,{ }^{* *} p<0.01$, and ${ }^{* *} p<0.001$.

b. Freeze-Dried Powders

According to the analysis of correlation between cell survival (\%) and particle size distribution values $\left(D_{10}, D_{50}, D_{90}\right.$, and span) of freeze-dried powders, there was also a highly significant $(p<0.05)$ negative correlation between the variables (Figure 3$)$. These results may suggest that the smaller the particles, the higher the cell survival $(\%)$. Furthermore, there was a significant $(p<0.05)$ positive correlation between cell survival and span. Similar results were observed for spray dried powders. It is important to notice that the particle size of the freeze-dried powders is affected by the grinding time/conditions [29]. Hence, the milling conditions for freeze-dried samples were previously standardized in a preliminary study, and $50 \mathrm{~g}$ of the grams/batch of material was milled for 1 minute at room temperature. 


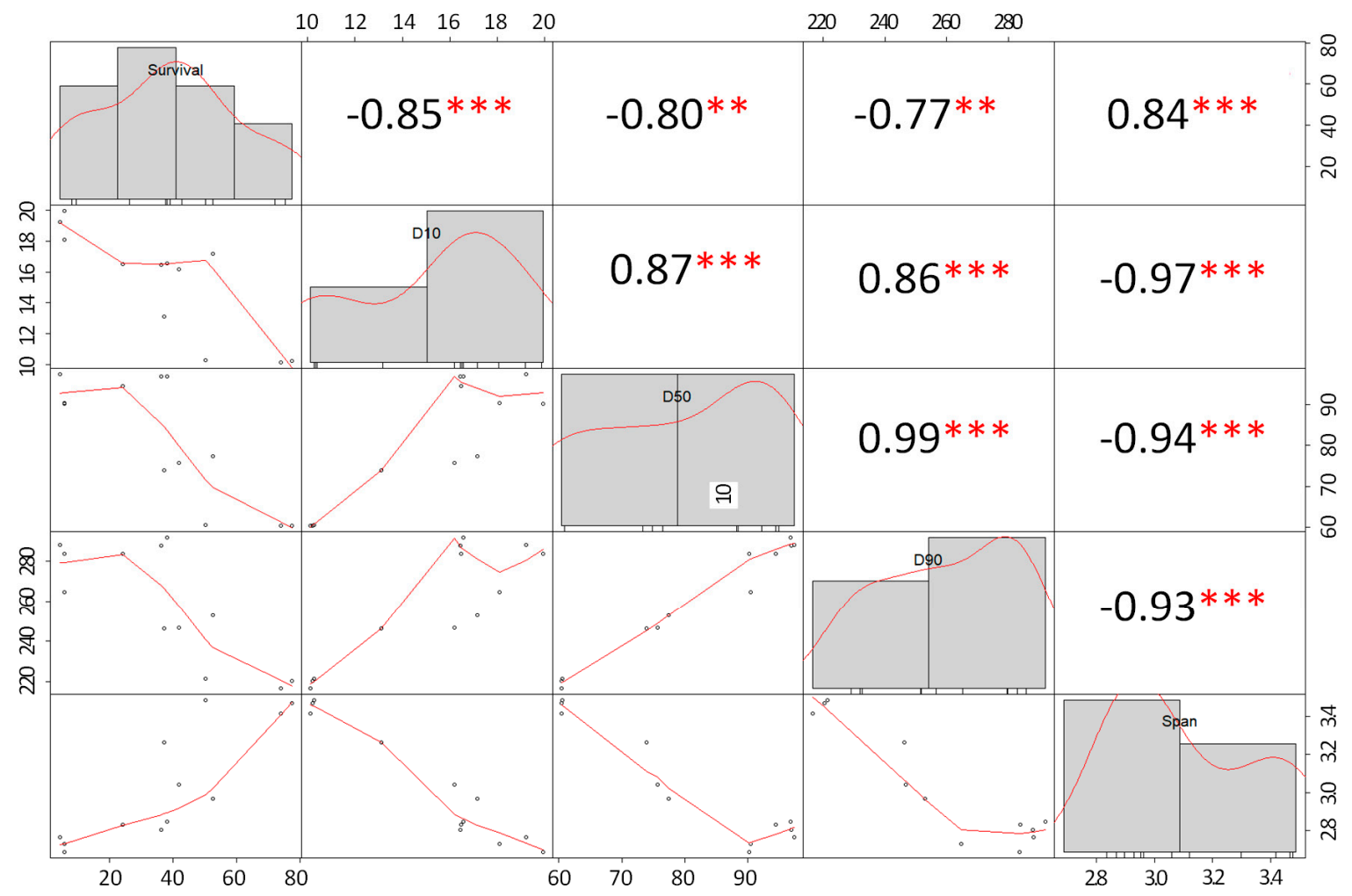

Figure 3. Analysis of correlation between particle size distribution (D10, D50, D90, and span) vs. the survival of probiotic cells in freeze-dried powders (units, survival $=\%, \mathrm{D} 10, \mathrm{D} 50, \mathrm{D} 90=\mu \mathrm{m}$ ). The distribution of each variable is presented in the diagonal. On the left of the diagonal, the bivariate scatter plots with a fitted line are shown. The output numbers represent the correlation coefficient. The stars represent the $p$-value of the correlations: ${ }^{*} p<0.05,{ }^{* *} p<0.01$, and ${ }^{* * *} p<0.001$.

\subsection{Moisture Content and Water Activity}

Moisture content and particle size data are presented in Table 3. For every drying technology and encapsulant, UHPH reduced the moisture content of the powders significantly, and in several cases, the moisture content saw reductions approaching or exceeding $50 \%$. Reductions in water activity were overall much more modest.

Table 3. Moisture content and water activity values of UHPH-treated powders containing L. plantarum (NRRL B-1927).

\begin{tabular}{|c|c|c|c|c|c|}
\hline \multirow{2}{*}{$\begin{array}{l}\text { Drying } \\
\text { Method }\end{array}$} & \multirow{2}{*}{$\begin{array}{c}\text { Encapsulating } \\
\text { Material }\end{array}$} & \multicolumn{2}{|c|}{ NO-UHPH } & \multicolumn{2}{|c|}{ UHPH (150 Mpa) } \\
\hline & & Moisture (\%) & Water Activity $\left(a_{w}\right)$ & Moisture (\%) & Water Activity $\left(a_{w}\right)$ \\
\hline $\mathrm{CC}$ & SPI & $4.35 \pm 0.09^{\mathrm{b}, \mathrm{A}}$ & $0.22 \pm 0.00^{\mathrm{a}, \mathrm{B}}$ & $3.81 \pm 0.43^{a, B}$ & $0.23 \pm 0.00^{\mathrm{a}, \mathrm{A}}$ \\
\hline $\mathrm{CC}$ & WPI & $5.18 \pm 0.16^{a, A}$ & $0.22 \pm 0.00^{a, A}$ & $3.89 \pm 0.42^{a, B}$ & $0.21 \pm 0.01^{\mathrm{a}, \mathrm{B}}$ \\
\hline MX & SPI & $4.16 \pm 0.22^{\mathrm{b}, \mathrm{A}}$ & $0.20 \pm 0.00^{\mathrm{b}, \mathrm{A}}$ & $2.25 \pm 0.11^{\mathrm{b}, \mathrm{A}}$ & $0.15 \pm 0.01^{\mathrm{b}, \mathrm{B}}$ \\
\hline MX & WPI & $4.83 \pm 0.25^{\mathrm{a}, \mathrm{A}}$ & $0.22 \pm 0.00^{a, A}$ & $3.79 \pm 0.07^{a, B}$ & $0.21 \pm 0.02^{\mathrm{a}, \mathrm{A}}$ \\
\hline FD & SPI & $1.03 \pm 0.05^{\mathrm{d}, \mathrm{A}}$ & $0.03 \pm 0.00^{\mathrm{d}, \mathrm{A}}$ & $0.41 \pm 0.07^{\mathrm{c}, \mathrm{B}}$ & $0.04 \pm 0.00^{\mathrm{c}, \mathrm{A}}$ \\
\hline FD & WPI & $2.04 \pm 0.12^{\mathrm{c}, \mathrm{A}}$ & $0.06 \pm 0.00^{\mathrm{c}, \mathrm{A}}$ & $0.24 \pm 0.09^{c, B}$ & $0.03 \pm 0.00^{c, B}$ \\
\hline
\end{tabular}

Means $\pm \mathrm{SD}, n=3$. Particle sizes followed by different miniscule (a, b, c, etc.) lettera in the same column are significantly different $(p<0.05)$. Particle sizes followed by different majuscule $(\mathrm{A}, \mathrm{B}, \mathrm{C}$, etc.) letters in the same row for a given measure (moisture or water activity) are significantly different $(p<0.05)$. 


\section{Discussion}

\subsection{Survivability of L. plantarum NRRL B-1927 Powders}

The increase in survivability seen between the untreated and UHPH-treated encapsulants supports the hypothesis that UHPH alters the encapsulant, allowing it to adopt a more protective configuration, thereby better protecting the probiotic cells. While the exact nature of the structural changes are beyond the scope of this work, previous studies do offer some insight on the potential phenomenon involved. Cavender and Kerr [17] suggested that an interaction between proteins and carbohydrate stabilizers was responsible for profound changes in the viscosity of the ice cream mix and Laneuville, et al. [30] created whey protein/polysaccharide complexes with increased viscosity using UHPH and attributed some of the effect on the physical disruption of tightly bound fibrous complexes. Zamora, Ferragut, Jaramillo, Guamis and Trujillo [18] examined the effect of UHPH on the cheese-making properties of milk, finding that at lower pressures $(<230 \mathrm{MPa})$, curds formed more readily and those curds tended to hold more moisture, strongly suggesting conformational changes in the constituents were allowing for more and/or better interactions. Similar effects have also been seen in soy yogurt that was made from UHPH-treated soymilk [24], and SPI-based emulsions [25], with the latter study suggesting the homogenization increased protein-protein interactions via the hydrophobic effect. Looking at a different legume proteins, Dong, Zhao, Yang, Yang, Shi and Jiang [23] noted increases in water-holding capacity, emulsifying activity and foaming capacity in a peanut protein isolate that had been treated with high-pressure homogenization (pressures $\leq 80 \mathrm{MPa}$ ).

Previous work examining the interaction of encapsulants with the entrained bacterial cells also offer some potential insight into the potential changes that occur to the encapsulants during UHPH. For example, Gong, Di, Yi, Sun, Zhang and Han [13] examined the protective effects of SPI and milk basic proteins (the basic protein fraction of WPI) with and without treatment with transglutaminase, and suggested that electrostatic interaction, particularly between positively charged protein sidechains and bacterial cells, resulted in increased survival. If a similar effect is responsible for the increased survival seen in this study, it could be due to conformational changes brought about by UHPH exposing more positively charged areas, or cleavage of the proteins into subunits with differing overall charges-some of which were positive. Soukoulis, et al. [31] suggests that whey proteins provide antioxidant properties due to sulfur-containing amino acids and are able to prevent lethal oxidative membrane damage during drying. This could help explain the lack of improvement in survivability during MXSD and FD with WPI-in these more gentle drying technologies, the primary cause of cell death might be membrane oxidation, and as the antioxidant sulfur-rich amino acids lie primarily near the surface in $\beta$-Lactoglobulin [32] (the dominant protein in WPI), cleavage or denaturation due to UHPH would not change the ability of those side chains to interact with oxygen species. This might also help explain the differences in WPI and SPI in MXSD and FD, as soy proteins are well known to be low in sulfur-rich amino acids [33-35] and the native conformation of soy proteins relies upon disulfide bridges to stabilize the tertiary structure [36].

In the current study, profound increases in survivability due to UHPH were seen in all of the encapsulant/drying technology combinations, except for MXSD and FD with WPI as the encapsulants-for which, there was no statistically significant change in survival. It is important to note that those combinations had the highest survival rates in the non-UHPH samples, and so they may represent the practical limit of survivability of the strain during drying in general. The explanation behind the observed results is likely due to changes in protein size and/or conformation. This is similar to the findings of Guraya and James [37], who showed that rice proteins became more soluble and starch granules became smaller after UHPH. The difference in survivability change due to UHPH between the two spray drying technologies is likely related to differences in the two techniques. MXSD is thought to be more gentle, as CCSD exposes liquid product to higher initial temperatures, which may injure bacterial cells more profoundly [5]. Thus, the need for a more protective encapsulant is lower in MXSD, and so much of the improvement in SPI functionality is wasted there. In CCSD, 
however, a 300\% increase in survivability was seen, and both the UHPH WPI and UHPH SPI samples had survivability greater than that of freeze drying with untreated isolates, which may be enough to justify the use of UHPH-treated encapsulants.

Survivability during freeze drying of the untreated samples was interesting, as SPI showed survival rates equal to or lower than the spray drying methods, while untreated WPI showed the highest survivability during freeze drying. Interestingly, treating SPI with UHPH seems to remedy the deficiency seen during freeze drying, as the treated samples showed the greatest increase in survivability-over $600 \%$. While this might seem promising, the combination of the two technologies (freeze drying and UHPH) would likely be cost prohibitive for manufacturers, and the overall survivability of those samples was equal to or less than that of the UHPH spray dried samples.

\subsection{Particle Size}

Particle size is an important property that can affect the practical functionality of powdered ingredients, influencing dispersibility, mouthfeel and appearance [38,39]. It has also been suggested that larger particles are better able to protect probiotic cells, at the expense of dispersibility [39]. While this may initially suggest that the untreated FD samples would perhaps have the best survival, the survivability data does not bear this out-FD SPI had the same particle size in the control and UHPH samples, but the survivability differences between the two were profound. Instead, it is most likely that the particles seen in the FD samples, both treated and untreated, are likely agglomerations of smaller particles, created due to the bulk nature of freeze drying, while the SD methods, which dry individual droplets would be expected to produce finer particles. When looking at the effect of UHPH on particle size, the fact that particle sizes tended to decrease when treated encapsulants were used is not entirely surprising —not only do multiple studies show the technology can reduce particle sizes $[14,15,40,41]$, but there is also the likelihood that the conformational changes made to the proteins open up additional sites of interaction, thereby allowing the formation of capsules with fewer proteins. Confirming this would require advanced microscopic techniques, which the authors are already pursuing for future publication.

Moreover, our observations are in agreement with those published by Würth, et al. [42] who reported an inverse (negative) correlation between the mean particle size $\left(\mathrm{D}_{50}\right)$ of spray dried skim milk powders produced at $155^{\circ} \mathrm{C}$ and the survival of Lactobacillus paracasei ssp. The authors reported survival rates (\%) of probiotic cells above $50 \%$ in particles with a $\mathrm{D}_{50} \approx 5 \mu \mathrm{m}$; while powders with a $\mathrm{D}_{50} \approx 10 \mu \mathrm{m}$ had survival rates below $10 \%$. In general, MX powders and UHPH-treated powders had smaller particles sizes than CC- and NO-UHPH-treated powders, respectively. Interestingly, powders with small particle sizes had higher cell survival rates (especially in spray dried powders). This effect may be because bigger particles have longer residence times inside the dryer chamber and, therefore, suffer higher thermal degradation. It is important to note that our analysis of correlation does not prove causation; rather, it is a tool to understand the complexity of the data. Therefore, the high survival rates $(\%)$ observed in our study may not be attributed to the particle size of the powders solely.

\subsection{Moisture Content and Water Activity}

The moisture content and water activity of dried probiotic powders are important factors in predicting stability during storage, with higher values correlated with poor survivability [12,43-46]. In fact, it has been suggested that $5 \%$ is the critical moisture content for long-term stability, with values higher than this being correlated with poor stability [12]. In the current study, the spray dried WPI control samples had moisture activities above this value (CCSD) or within one standard deviation of it (MXSD), while the SPI control samples were slightly below the value. The UHPH samples which were spray dried were all below the critical value, indicating the technology could be used to ensure the production of consistent low-moisture probiotic powders. FD samples showed more profound changes in moisture content, but all were far below the critical value.

The limited or non-existent decreases in water activity between the control and UHPH samples suggest that the moisture differences seen are likely a result of losses in free water, rather than bound 
water. Further, while one of the freeze-dried samples did show an increase in mean $A_{W}$ of 0.01 units, both this difference and the measures of $A_{w}$ upon which it was determined are close to the technical limits of the instrument. For all samples, the $A_{w}$ measures were sufficiently low to prevent the growth of undesirable microbes, and would result in nearly non-existent enzymatic activity [47]. Further, while these levels are known to encourage lipid oxidation, the lack of lipids in the encapsulants should also render that concern moot as well. Thus it can be assumed that, when properly packaged and stored, all of the probiotic powders produced in this study should have a reasonably long shelf life, and a study is currently underway to better quantify this and to determine what effect, if any, UHPH treatment has on storage stability.

\section{Conclusions}

UHPH provides interesting potential to improve the encapsulating ability of protein isolates during spray drying, reducing particle sizes, moisture content and improving survivability. The study also demonstrated that probiotic powders with high cell survival can be effectively produced by mixed-flow spray drying. In particular, for UHPH-treated a soy protein isolate allows the use of concurrent spray drying, the most common type of spray drying, to produce probiotic powders that have no dairy-related concerns with markedly lower culture loss than the more expensive and slower freeze drying process. While the technology clearly can improve survival during the spray drying process, it remains to be seen what effect the process will have on culture survival during storage and, perhaps most importantly, during digestion. While it is likely that the changes in the encapsulants which are responsible for protecting the bacteria during drying will also protect them during storage and digestion, it is possible that the conformational changes might have a deleterious effect, and determining whether this is the case is important before a recommendation to the industry can be made. Therefore, in addition to investigating the effects on other probiotic strains and optimizing drying conditions, future studies should also be aimed at these important questions.

Author Contributions: Conceptualization, G.A.C. and K.E.M.-S.; Methodology, G.A.C. and K.E.M.-S.; formal analysis, K.E.M.-S.; investigation, K.H.J., N.J. and M.Y.; resources, G.A.C. and K.E.M.-S.; data curation, N.J.; writing-original draft preparation, G.A.C.; writing-review and editing, G.A.C.; supervision, G.A.C. and K.E.M.-S.; project administration, G.A.C. and K.E.M.-S.; funding acquisition, G.A.C.

Funding: This research received no external funding.

Acknowledgments: The authors would like to graciously thank the Archer Daniels Midland Corporation for their generous donation of Soy Protein Isolate, and the rapid speed with which they sent additional amounts.

Conflicts of Interest: The authors declare no conflict of interest.

\section{References}

1. Champagne, C.P.; Gomes da Cruz, A.; Daga, M. Strategies to improve the functionality of probiotics in supplements and foods. Curr. Opin. Food Sci. 2018, 22, 160-166. [CrossRef]

2. Bruhn, C.M.; Bruhn, J.C.; Cotter, A.; Garrett, C.; Klenk, M.; Powell, C.; Stanford, G.; Steinbring, Y.; West, E. Consumer Attitudes Toward Use of Probiotic Cultures. J. Food Sci. 2002, 67, 1969-1972. [CrossRef]

3. Saarela, M.; Mogensen, G.; Fondén, R.; Mättö, J.; Mattila-Sandholm, T. Probiotic bacteria: Safety, functional and technological properties. J. Biotechnol. 2000, 84, 197-215. [CrossRef]

4. Mattila-Sandholm, T.; Myllärinen, P.; Crittenden, R.; Mogensen, G.; Fondén, R.; Saarela, M. Technological challenges for future probiotic foods. Int. Dairy J. 2002, 12, 173-182. [CrossRef]

5. Murugesan, R.; Orsat, V. Spray Drying for the Production of Nutraceutical Ingredients-A Review. Food Bioprocess Technol. 2012, 5, 3-14. [CrossRef]

6. Hadzieva, J.; Mladenovska, K.; Crcarevska, M.S.; Dodov, M.G.; Dimchevska, S.; Geškovski, N.; Grozdanov, A.; Popovski, E.; Petruševski, G.; Chachorovska, M.; et al. Lactobacillus casei Encapsulated in Soy Protein Isolate and Alginate Microparticles Prepared by Spray Drying. Food Technol. Biotechnol. 2017, 55, 173-186. [CrossRef] [PubMed] 
7. Huq, T.; Khan, A.; Khan, R.A.; Riedl, B.; Lacroix, M. Encapsulation of Probiotic Bacteria in Biopolymeric System. Crit. Rev. Food Sci. Nutr. 2013, 53, 909-916. [CrossRef]

8. Oliver, C.M.; Augustin, M.A. Using dairy ingredients for encapsulation. In Dairy-Derived Ingredients; Corredig, M., Ed.; Woodhead Publishing: Sawston/Cambridge, UK, 2009; pp. 565-588. [CrossRef]

9. Cal, K.; Sollohub, K. Spray drying technique. I: Hardware and process parameters. J. Pharm. Sci. 2010, 99, 575-586. [CrossRef]

10. Reyes, V.; Chotiko, A.; Chouljenko, A.; Campbell, V.; Liu, C.; Theegala, C.; Sathivel, S. Influence of wall material on production of spray dried Lactobacillus plantarum NRRL B-4496 and its viability at different storage conditions. Dry. Technol. 2018, 36, 1738-1748. [CrossRef]

11. Reyes, V.; Chotiko, A.; Chouljenko, A.; Sathivel, S. Viability of Lactobacillus acidophilus NRRL B-4495 encapsulated with high maize starch, maltodextrin, and gum arabic. LWT 2018, 96, 642-647. [CrossRef]

12. Chávez, B.E.; Ledeboer, A.M. Drying of Probiotics: Optimization of Formulation and Process to Enhance Storage Survival. Dry. Technol. 2007, 25, 1193-1201. [CrossRef]

13. Gong, P.; Di, W.; Yi, H.; Sun, J.; Zhang, L.; Han, X. Improved viability of spray-dried Lactobacillus bulgaricus sp1.1 embedded in acidic-basic proteins treated with transglutaminase. Food Chem. 2019, 281, 204-212. [CrossRef] [PubMed]

14. Tan, J.; Kerr, W.L. Rheological properties and microstructure of tomato puree subject to continuous high pressure homogenization. J. Food Eng. 2015, 166, 45-54. [CrossRef]

15. Sidhu, J.S.; Singh, R.K. Ultra High Pressure Homogenization of Soy Milk: Effect on Quality Attributes during Storage. Beverages 2016, 2, 15. [CrossRef]

16. Paquin, P. Technological properties of high pressure homogenizers: The effect of fat globules, milk protiens and polysaccharides. Int. Dairy J. 1999, 9, 329-335. [CrossRef]

17. Cavender, G.A.; Kerr, W.L. Microfluidization of Full-fat Ice Cream Mixes: Effects of Gum Stabilizer Choice on Physical and Sensory Changes. J. Food Process Eng. 2013, 36, 29-35. [CrossRef]

18. Zamora, A.; Ferragut, V.; Jaramillo, P.D.; Guamis, B.; Trujillo, A.J. Effects of Ultra-High Pressure Homogenization on the Cheese-Making Properties of Milk. J. Dairy Sci. 2007, 90, 13-23. [CrossRef]

19. Valdéz, J.C.; Peral, M.C.; Rachid, M.; Santana, M.; Perdigón, G. Interference of Lactobacillus plantarum with Pseudomonas aeruginosa in vitro and in infected burns: The potential use of probiotics in wound treatment. Clin. Microbiol. Infect. 2005, 11, 472-479. [CrossRef]

20. Khemariya, P.; Singh, S.; Jaiswal, N.; Chaurasia, S.N.S. Isolation and Identification of Lactobacillus plantarum from Vegetable Samples. Food Biotechnol. 2016, 30, 49-62. [CrossRef]

21. Blackwood, B.P.; Yuan, C.Y.; Wood, D.R.; Nicolas, J.D.; Grothaus, J.S.; Hunter, C.J. Probiotic Lactobacillus Species Strengthen Intestinal Barrier Function and Tight Junction Integrity in Experimental Necrotizing Enterocolitis. J. Probiotics Health 2017, 5, 159. [CrossRef]

22. USDA-ARS. Lactobacillus Plantarum NRRL B-1927. 2019. Available online: https://nrrl.ncaur.usda.gov/cgibin/usda/prokaryote/report.html?nrrlcodes=B\%2d1927 (accessed on 15 June 2019).

23. Dong, X.; Zhao, M.; Yang, B.; Yang, X.; Shi, J.; Jiang, Y. Effect of High-Pressure Homogenization on the functional Property of Peanut Protein. J. Food Process Eng. 2011, 34, 2191-2204. [CrossRef]

24. Cruz, N.S.; Capellas, M.; Jaramillo, D.P.; Trujillo, A.J.; Guamis, B.; Ferragut, V. Soymilk treated by ultra high-pressure homogenization: Acid coagulation properties and characteristics of a soy-yogurt product. Food Hydrocoll. 2009, 23, 490-496. [CrossRef]

25. Floury, J.; Desrumaux, A.; Legrand, J. Effect of Ultra-high-pressure Homogenization on Structure and on Rheological Properties of Soy Protein-stabilized Emulsions. J. Food Sci. 2002, 67, 3388-3395. [CrossRef]

26. Lapsiri, W.; Bhandari, B.; Wanchaitanawong, P. Viability of Lactobacillus plantarum TISTR 2075 in Different Protectants during Spray Drying and Storage. Dry. Technol. 2012, 30, 1407-1412. [CrossRef]

27. Barbosa, J.; Borges, S.; Amorim, M.; Pereira, M.J.; Oliveira, A.; Pintado, M.E.; Teixeira, P. Comparison of spray drying, freeze drying and convective hot air drying for the production of a probiotic orange powder. J. Funct. Foods 2015, 17, 340-351. [CrossRef]

28. Mis Solval, K.; Bankston, J.D.; Bechtel, P.J.; Sathivel, S. Physicochemical Properties of Microencapsulated $\omega-3$ Salmon Oil with Egg White Powder. J. Food Sci. 2016, 81, E600-E609. [CrossRef] [PubMed]

29. Karam, M.C.; Petit, J.; Zimmer, D.; Baudelaire Djantou, E.; Scher, J. Effects of drying and grinding in production of fruit and vegetable powders: A review. J. Food Eng. 2016, 188, 32-49. [CrossRef] 
30. Laneuville, S.I.; Paquin, P.; Turgeon, S.L. Effect of preparation conditions on the characteristics of whey protein-xanthan gum complexes. Food Hydrocoll. 2000, 14, 305-314. [CrossRef]

31. Soukoulis, C.; Behboudi-Jobbehdar, S.; Yonekura, L.; Parmenter, C.; Fisk, I. Impact of Milk Protein Type on the Viability and Storage Stability of Microencapsulated Lactobacillus acidophilus NCIMB 701748 Using Spray Drying. Food Bioprocess Technol. 2014, 7, 1255-1268. [CrossRef]

32. Creamer, L.K.; Bienvenue, A.; Nilsson, H.; Paulsson, M.; van Wanroij, M.; Lowe, E.K.; Anema, S.G.; Boland, M.J.; Jiménez-Flores, R. Heat-Induced Redistribution of Disulfide Bonds in Milk Proteins. 1. Bovine $\beta$-Lactoglobulin. J. Agric. Food Chem. 2004, 52, 7660-7668. [CrossRef]

33. González-Ferrero, C.; Irache, J.M.; González-Navarro, C.J. Soybean protein-based microparticles for oral delivery of probiotics with improved stability during storage and gut resistance. Food Chem. 2018, 239, 879-888. [CrossRef] [PubMed]

34. Hidayat, M.; Sujatno, M.; Sutadipura, N.; Faried, A. $\beta$-Conglycinin Content Obtained from Two Soybean Varieties Using Different Preparation and Extraction Methods. HAYATI J. Biosci. 2011, 18, 37-42. [CrossRef]

35. Thanh, V.H.; Shibasaki, K. Major proteins of soybean seeds. Subunit structure of beta-conglycinin. J. Agric. Food Chem. 1978, 26, 692-695. [CrossRef]

36. Zhu, Y.; Li, Y.; Wu, C.; Teng, F.; Qi, B.; Zhang, X.; Zhou, L.; Yu, G.; Wang, H.; Zhang, S.; et al. Stability Mechanism of Two Soybean Protein-Phosphatidylcholine Nanoemulsion Preparation Methods from a Structural Perspective: A Raman Spectroscopy Analysis. Sci. Rep. 2019, 9, 6985. [CrossRef] [PubMed]

37. Guraya, H.S.; James, C. Deagglomeration of Rice Starch-Protein Aggregates by High-Pressure Homogenization. Starch Stärke 2002, 54, 108-116. [CrossRef]

38. Sharma, M.; Kadam, D.M.; Chadha, S.; Wilson, R.A.; Gupta, R.K. Influence of particle size on physical and sensory attributes of mango pulp powder. Int. Agrophys. 2013, 27, 323-328. [CrossRef]

39. Zhao, R.; Sun, J.; Torley, P.; Wang, D.; Niu, S. Measurement of particle diameter of Lactobacillus acidophilus microcapsule by spray drying and analysis on its microstructure. World J. Microbiol. Biotechnol. 2008, 24, 1349-1354. [CrossRef]

40. Ciron, C.I.E.; Gee, V.L.; Kelly, A.L.; Auty, M.A.E. Comparison of the effects of high-pressure microfluidization and conventional homogenization of milk on particle size, water retention and texture of non-fat and low-fat yoghurts. Int. Dairy J. 2010, 20, 314-320. [CrossRef]

41. Song, X.; Zhou, C.; Fu, F.; Chen, Z.; Wu, Q. Effect of high-pressure homogenization on particle size and film properties of soy protein isolate. Ind. Crops Prod. 2013, 43, 538-544. [CrossRef]

42. Würth, R.; Foerst, P.; Kulozik, U. Effects of skim milk concentrate dry matter and spray drying air temperature on formation of capsules with varying particle size and the survival microbial cultures in a microcapsule matrix. Dry. Technol. 2018, 36, 93-99. [CrossRef]

43. Ananta, E.; Birkeland, S.E.; Corcoran, B.; Fitzgerald, G.; Hinz, S.; Klijn, A.; Mättö, J.; Mercernier, A.; Nilsson, U.; Nyman, M.; et al. Processing effects on the nutritional advancement of probiotics and prebiotics. Microb. Ecol. Health Dis. 2004, 16, 113-124. [CrossRef]

44. Picot, A.; Lacroix, C. Encapsulation of bifidobacteria in whey protein-based microcapsules and survival in simulated gastrointestinal conditions and in yoghurt. Int. Dairy J. 2004, 14, 505-515. [CrossRef]

45. Abe, F.; Miyauchi, H.; Uchijima, A.; Yaeshima, T.; Iwatsuki, K. Effects of storage temperature and water activity on the survival of bifidobacteria in powder form. Int. J. Dairy Technol. 2009, 62, 234-239. [CrossRef]

46. Weinbreck, F.; Bodnár, I.; Marco, M.L. Can encapsulation lengthen the shelf-life of probiotic bacteria in dry products? Int. J. Food Microbiol. 2010, 136, 364-367. [CrossRef]

47. Damodaran, S.; Parkin, K.L. Fennema's Food Chemistry; CRC Press: Boca Raton, FL, USA, 2017.

(C) 2019 by the authors. Licensee MDPI, Basel, Switzerland. This article is an open access article distributed under the terms and conditions of the Creative Commons Attribution (CC BY) license (http://creativecommons.org/licenses/by/4.0/). 